"South African generation-X online shopper satisfaction and their repurchase intentions"

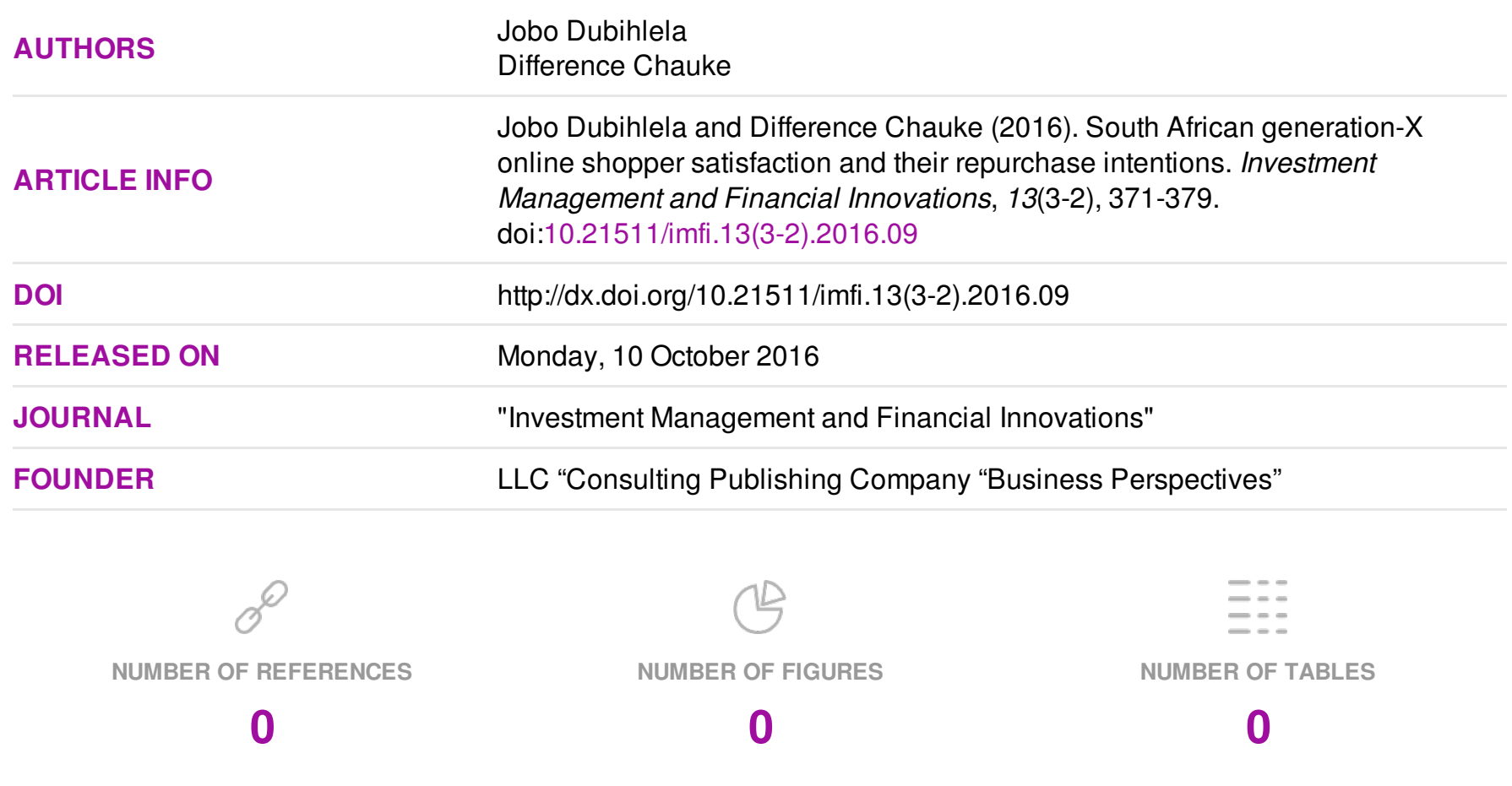

(C) The author(s) 2023. This publication is an open access article. 
Jobo Dubihlela (South Africa), Difference Chauke (South Africa)

\title{
South African generation-X online shopper satisfaction and their repurchase intentions
}

\begin{abstract}
The growth of online shopping channels gradually forces brick and mortar retailers to explore the importance of online shopping trends and online customer behavior. While maintaining customer satisfaction has been recognized as one of the essential factors for business survival and growth, this has not been sufficiently explored for online shopping platforms. Understanding what online constructs appeal to generation-X consumers is critical for organization that would want to pursue virtual business platforms. From a brief literature review in this study, it could be said that online customer satisfaction and its influences on online repurchase intentions in the South African retailing environment remain sparsely researched. Therefore, this study seeks to analyze the dimensions of online customer satisfaction and regress the online satisfaction dimensions on repurchase intentions of generation-X consumers. An attempt is made to apply the theory of planned behavior and social exchange in the adapted conceptual of the study. These theories are deemed to provide an appropriate theoretical grounding to this study. The target population was South African generation-X online consumers in Gauteng. A total of 377 questionnaires were received for data analysis. Implications of the research findings are discussed and limitations and future research directions are provided.
\end{abstract}

Keywords: online shoppers, online customer satisfaction, repurchase intentions, generation-X consumers, South Africa.

JEL Classification: M1, M30, M31, L10.

\section{Introduction}

Many organizations are resorting to virtual online retailing platforms due to its exponential growth, futuristic potential and global-reach capability. Convenience, cost-effectiveness and the speed offered by online shopping suites most agile businesses operating in dynamic consumers markets. It is acknowledged that consumers' shopping habits have changed and their Internet usage rate has increased especially with the advances in virtual channelling. The Internet usage has increased due to the advancement of technology and the dynamics of virtual communications, coupled with the pervasive knowledge of the consumer. Therefore, understanding online consumers is important in today's economy. It is also important to understand buyer motivation and the satisfaction of online customers after making a purchase. Lin, Fang and $\mathrm{Tu}$ (2010) assert that learning how satisfied the customers are with online shopping is crucial to establishing and maintaining repeat-purchase intention. Retailers have realized that it is less expensive to venture into international market via the Internet. Lin et al. (2010) further indicate that if online businesses want to increase revenue, customers should shop four times or more from them, or the company should establish a loyalty relationship for 18 months. The question is how to entice a customer to shop from the same

(C) Jobo Dubihlela, Difference Chauke, 2016.

Jobo Dubihlela, Professor, School of Accounting Sciences, Faculty of Business \& Management Sciences, Cape Peninsula University of Technology, South Africa.

Difference Chauke, Faculty of Management Sciences, Vaal University of Technology, South Africa. online retailer. It is easier to compare products online than it is in a traditional retail outlet. For business, online retailers reduce the cost of purchasing. The nature of distribution in online context eliminates the role of middleman and, hence, cuts a considerable cost to the organization (Karamiet al., 2014, p. 6). Moreover, organizations that engage in online business do not need to rent or own a space of a building and, in that way, avoid expenses.

On the other hand, online business provides consumers with quite a good number of benefits ranging from more interactive communications present in the system, both the distribution and the delivery are efficient and fast, product and services that are available in online business are more customized and one can get almost what he orders if not exactly (Pratminingsih, Lipuringtyas \& Rimenta, 2013). In addition, the range that exists between products or services in different forms gives a very competitive advantage to online customers, as they can easily compare prices of the products/services (Karami et al., 2014). The study takes the consumer satisfaction to be the predictor variable which influences consumer repurchase intention. The purpose of the present study is supplying a literature that can help of online stakeholder. On top of that, the findings reinforce many existing literature in the context of the online shopping on the factors influencing customer repurchase intentions. It prepares for in advance functional information for controlling businesses particularly in online shopping factors effect on customer repurchase. The findings of this study will assist businessmen in developing their internet and 
online shopping. In addition, the paper seeks to contribute new body knowledge to the existing retail businesses in a dual economy like South Africa. Studies on online consumer purchase behavior would require a thorough understanding of two fundamental theories: the theory of planned behavior (TPB) and the social exchange theory (SET), to put them into perspective.

The remainder of this article provides theoretical background of the study on the theories of TPB and SET, literature review on the research variables: customer satisfaction and repurchase intention. The study also provides the research methodology and data analysis. Finally, results are discussed, implications provided and limitations and future research directions are highlighted.

\section{Theoretical background}

The study has adopted the theory of planned behavior (TPB) and the social exchange theory (SET). TPB has been utilized as a platform for satisfaction studies (Wimsatt, 2012, p. 7). The SET contends that a basic motivation for interaction is the seeking of rewards and avoidance of punishments (Chinomona, Masinge \& Sandada, 2014, p. 332). As such, SET argues that attitudes and behaviors are determined by the rewards of interaction minus the penalty. This implies that rewarding customers for a particular positive action leads to intention to repurchase.

1.1. Theory of planned behavior. TPB is an extension of the theory of reasoned action which also deals with behavioral intentions (Myers \& Mintu-Wimsatt, 2012, p. 3). Similarly, as with TRA, the chief aspect in the theory of planned behavior is a person's intention to undertake the behavior (Ajzen, 1991, p. 181). One key aspect of TPB is behavioral intentions, especially the intention of taking on a particular behavior or a specific product (Al-Swidi, Behjati \& Shahzad, 2012, p. 36). This theory focuses on a persons' intention to perform a specific activity based on his/her attitude toward that specific activity along with the subjective behavioral norms held by that person (Ajzen, 1991, p. 181). The theory of plan behavior (TPB) indicates that behavior intention can be used for predicting actual behavior (Al-Swidi et al., 2012, p. 39). Certain customers feel strongly about continually transacting with the same business.

1.2. Social exchange theory. The study also pays attention to the application of social exchange theory (SET) in an online shopping context. Originating in the 1950s, and based on psychology, the SET has been used by researchers to examine social behaviors (Shiau \& Luo, 2012, p. 432). SET embraces the fundamental concepts of modern economics foundational for analyzing human behavior and relationships to determine social structure complexity. Individuals or consumers typically expect benefits in return, such as personal affection, trust, gratitude, and economic return when they act according to social norms. The SET model suggests that individuals and organizations interact to make as great as possible their rewards, and reduce their costs (Al-Swidi et al., 2012, p. 37). The social exchange theory has been applied recently in social networking studies, although the application of the SET area is yet to be fully examined. Liu, Chen, Liu, Lin and Chan (2010, p. 123) explain the process of social exchange as a set of related activities exchanged. Therefore, interpersonal interactions from a cost-benefit perspective are an exchange where actors acquire benefits (Shiau \& Luo, 2012, p. 432). The model of social exchange suggests that consumers and businesses interact to make great profits and minimize their costs. In the modern era of the Internet, it is noted that trust is more important than ever before, as it may determine the growth of the Internet and it governs the web as well (Luo, 2002, p. 111). The study applied the social exchange theory to understand the knowledge-sharing concept in the online shopping context. Hence, these theories (planned behavior, social exchange) will serve as a platform to analyze the impact of online shopping satisfaction on repurchase intentions.

\section{Literature review and hypotheses development}

2.1. Customer satisfaction. Customer satisfaction is broadly viewed as "the most crucial route to significant and sustained marketing performance" (Awan \& Rehman, 2014, p. 18). The authors go on to say that customer satisfaction strategy has built a great deal of consideration during the past decades. Customer satisfaction is fundamental to the growth and expansion of business, as it leads to an increase in market share, and to acquiring repeat and referral business, which, ultimately, results in greater profitability (Donnelly, 2009, p. 69). The satisfaction construct is often used as a marketing benchmark to examine the company performance (Thakur \& Singh, 2012, p. 37). Bagram and Khan (2012) maintain that customer satisfaction involves features or characteristics that can satisfy the need or want of a customer.

Consumer satisfaction is also seen as a key performance indicator within a business (Adolphson, Eklöf \& Parmler, 2012). There is evidence that prioritizing customer satisfaction is essential to improve the business' profitability (Al-Swidi et al., 2012, p. 36; Cengiz, 2010; Zhang \& Pan, 2009) the two being positively related. Businesses, therefore, 
now elevate the role of customers to that of stakeholders as an exceptional business strategy, primarily because online satisfaction is fundamental for business success (Chinomona et al., 2014). Unsatisfied consumers are also quick to switch from the brand which fails to fulfil basic requirements. Furthermore, Morgan (2009) noted that a dissatisfied customer may relate a bad experience to 5 to 15 other people, eroding potential patronage of the service provider. Satisfaction is an important precursor in promoting customer repurchase behavior (Tsai \& Haung, 2007), as it can affect a buyer's decision to continue a relationship with the organization (Ndubisi, Malhotra \& Chan, 2009).

Lin, Fang and $\mathrm{Tu}(2010$, p. 1528) claim that satisfaction symbolizes the overall experience of customers thus far, and maintains that customer satisfaction is the key determinant of repurchase intention. Moreover, Kiyani, Niazi, Rizvi and Khan (2012, p. 491) assert that customer satisfaction is the most important aspect of repurchase behavior beside other variables in online environment. Therefore, online retailers must focus on a more comprehensive approach towards relationship marketing that includes customer satisfaction, which will result in retaining current customers and generation of positive word of mouth (Al-Swidi et al., 2012, p. 36). Competitive advantage can be created through the customer satisfaction. However, Ajzen and Fishbein (1980, p. 6) assert that attitude is inclined beforehand to respond positively or negatively to the information system. Therefore, the current research focuses on satisfaction instead of attitude to predict online consumers repurchase intention. Customer satisfaction could be measured by measuring satisfaction after a certain performance and by measuring satisfaction experienced by customers after purchasing a product or service (Lin et al., 2010, p. 1528).

Lin et al. (2010, p. 1528) propose the five ways of measuring satisfaction:

- Quality and experience of transacting from the store.

- The reliability and accuracy of the product or service advertized.

- The comparative enjoyment of shopping with one particular shop and another.

- The price satisfaction when comparing to the service or product.

- The prevalent overall feeling of satisfaction.

Furthermore, Donnelly (2009, p. 70) develops five models of satisfaction: three of those are claimed to be evaluative models on the bases of disconfirmation of expectation, and the other two are evaluative models resulting in non-rational processes.

\section{Repurchase intentions}

Online repurchase intention is the key issue in channelling literature, having been researched in different ways such as customer retention, intention to return, continuance to shop, and Internet sickness (Wen, Prybutok \& Xu, 2011, p. 15). There is a wide agreement on the crucial role of repurchase as the key behavioral outcome for relationship marketing in the marketing literature (Mosavi \& Ghaedi, 2012). In line with this observation, online repurchase intentions is a consumer's willingness to repurchase offerings from a particular website. Zhang, Fang, Wei, Ramsey, McCole and Chen (2011) maintain that consumer buying behavior can be understood in two stages, thus, encouraging people to purchase and enhancing them to repurchase. Repurchase intention refers to the consumer's willingness to buy for a long time from the same company (Cengiz, 2010). It can also refer to the individual's judgment about buying again a designated service from the same company (Lacey \& Morgan, 2009).

Hellier, Geursen, Carr and Rickard (2003) define repurchase intention as the individual's decision about repeatedly buying the product/service from the same company, taking into account his/her current situation and circumstances. First-time purchase is often used as a predictive measure of repurchase behavior. The decision to repurchase represents the customer's decision to engage in continuous consumption of the product. Seiders, Voss, Grewal and Godfrey (2005) and Yi and La (2004) confirm a positive relationship between repurchase intentions and customer satisfaction. According to Kaveh (2011), this relationship simplifies the matter, because, in real world, many factors converge in order to make a decision to repurchase. Increased costs of getting new customers are rising. Marketing managers now rely on repurchase intentions to predict sales and increase profits in a variety of marketing activities (Pérez, Sánchez, Abad, Carrillo \& Fernández, 2007), and demand forecasting for existing products. Similarly, academic researchers frequently use purchase intention as a proxy for repurchase behavior (Cengiz, 2010). Perhaps, most importantly, repurchase intentions are the most widely used indicator of customer satisfaction.

\section{Research design and methodology}

A positivist quantitative methodology was followed in this study. The rationale in picking a quantitative method was in attempt to enhance the accuracy of results through detailed statistical analysis and manage the impartiality and consistency that is necessary minimizing the element of subjectivity in the results. 
3.1. Sampling and data collection procedures. The target population for this study was South African generation-X online consumers in Gauteng. Physical distribution and collection of questionnaire were used to collect data. This method has the advantage of speed, is less costly and the researcher has control over respondent. A total number of 500 questionnaires were distributed. However, due to a variety of reasons, some of the questionnaires were not returned, while some were incomplete. Therefore, a total number of 326 usable questionnaires were received for analysis, representing a 65.2 percent response rate.

3.2. Instrument and measurement of the variables. A survey approach was chosen to gather information directly from generation-X online consumers in five cities/towns, namely, Vanderbijlpark, Vereeniging, Meyerton, Arconpark and Dennysville of Gauteng, South Africa. Snowball non-probability sampling technique was employed. To provide an adequate level of confidence in this study, a sample size of 500 respondents was targeted. The study used a structured questionnaire for data collection consisting of a series of questions to which participants responded. The survey instrument was a 3-page self-administered questionnaire. Research scales were operationalized using previous studies with similar topics and the sample. Proper modifications were made in order to fit the current research context and purpose. This study consists of two variables of which online customer satisfaction is measured by seven-item scales all adopted from Kim, Galliers, Shin, Ryoo and Kim (2012, p. 379). Customer repurchase intention used six-item scale measure all adopted from $\mathrm{Ha}$, Muthaly and Akamavi (2010, p. 886). All the measurement items were measured on a five-point Likert-type scales that was anchored by $1=$ strongly disagree to $5=$ strongly agree to express the degree of agreement. Individual scale items are listed in Appendix 1.

\subsection{Profile of the respondents}

3.3.1. Age and race of the respondents. The age composition of the sample reports that 38 percent $(n=124)$ of the respondents were between the age of 32-35 years, 35.3 percent $(n=115)$ were aged between $36-40$ years, 13.5 percent $(n=44)$ were aged between $41-45$ years, 8.6 percent $(n=28)$ represented the age group between $46-50$ years, and the 4.6 percent $(n=15)$ of the sample represented 51 years and above. It seems that online shopping business is mostly evolved within the age brackets of 32-50 years provided the majority of the respondents were aged between 32-35, with 38 percent $(n=124)$. Therefore, it can be concluded that online shopping requires individuals with online shopping experience and purchase powers.

Table 1. Respondents characteristics (age and race)

\begin{tabular}{|l|c|c|c|c|c|}
\hline \multicolumn{1}{|c|}{ Age of respondent } & Freq & $\%$ & Race & Freq & $\%$ \\
\hline $32-35$ years & 124 & 38 & Black & 180 & 55.2 \\
\hline $35-40$ years & 115 & 35.3 & White & 78 & 23.9 \\
\hline $41-45$ years & 44 & 13.5 & Coloured & 34 & 10.4 \\
\hline $46-50$ years & 28 & 8.6 & Indian & 34 & 10.4 \\
\hline 51 years and above & 15 & 4.6 & & & \\
\hline Total & 326 & 100 & Total & 326 & 100 \\
\hline
\end{tabular}

Table 1 provides the breakdown of ethnicity (population group). The majority of the respondents were Black-Africans $(52.2 \% ; n=180)$ followed by Whites with 23.9 percent $(n=78)$. Coloureds constituted 10.4 percent $(n=34)$ of the respondents altogether, same as Indians on 10.4 percent $(n=34)$. This shows that Black-Africans from the sampled respondents have the passion and desire to shop online, compared to other population groups.

3.3.2. Language of the respondents. Table 2 reports that 20.2 percent $(n=66)$ of the sample were Afrikaans speaking people, 7.4 percent $(n=24)$ of the respondents represented IsiZulu language, followed by Xitsonga with 7.1 percent $(n=23)$, SiSwati was represented by 3.4 percent $(n=11)$ of the respondents, 5.8 percent $(n=19)$ and 5.5 percent $(n=18)$ of the respondents represented IsiXhosa and Setswana languages, respectively, 19 percent $(n=62)$ of the total sample were English speaking people, 5.2 percent $(n=$ 17) of the respondents were Venda speaking group, Sesotho was represented in the sample by 11.35 percent $(n=37)$, the least percentage of the sample represented Ndebele with 1.8 percent $(n=6)$ of the respondents were IsiNdebele speaking people, 4.3 percent $(n=14)$ of the respondents represented Sepedi, while 8.9 percent $(n=29)$ represented other languages. It seems that southern Gauteng (Vaal Triangle) is dominated by an Afrikaansspeaking group within generation- $X$ consumers shopping online, followed by English-speaking people.

Table 2. Language of correspondence of the respondents

\begin{tabular}{|c|c|c|}
\hline $\begin{array}{c}\text { Mother tongue of the } \\
\text { respondents }\end{array}$ & Frequency & Percentage \\
\hline Afrikaans & 66 & 20.2 \\
\hline
\end{tabular}


Table 2 (cont.). Language of correspondence of the respondents

\begin{tabular}{|c|c|c|}
\hline $\begin{array}{c}\text { Mother tongue of the } \\
\text { respondents }\end{array}$ & Frequency & Percentage \\
\hline Xitsonga & 23 & 7.1 \\
\hline IsiZulu & 24 & 7.4 \\
\hline siSwati & 11 & 3.4 \\
\hline IsiXhosa & 19 & 5.8 \\
\hline Setswana & 18 & 5.5 \\
\hline English & 62 & 19 \\
\hline Tshivenda & 17 & 5.2 \\
\hline Sesotho & 37 & 11.3 \\
\hline IsiNdebele & 6 & 1.8 \\
\hline Sepedi & 14 & 4.3 \\
\hline Other & 29 & 8.9 \\
\hline Total & 326 & 100 \\
\hline
\end{tabular}

3.3.3. Educational status. In terms of educational background, Figure 1 shows that more than threequarters $(12 \%+41.1 \%+25.2 \%+14.7 \%=93 \%)$ of the respondents had a qualification from tertiary institutions. The majority of the respondents $(41.1 \%$; $n=134)$ had either diploma or degree, 25.2 percent of the respondents either had an honours or master's degree, 14.7 percent $(n=48)$ of the respondents had $\mathrm{PhD}$ or other equivalent qualification, 12 percent $(n=39)$ of the respondents had a college certificate. The reminder (small portion) of the respondents 7.1 percent $(n=23)$ either possess a grade 12 certificate, or had no formal education at all. North et al. (2003, p. 61) study is in agreement with these findings that online consumers tend to have higher educational levels.

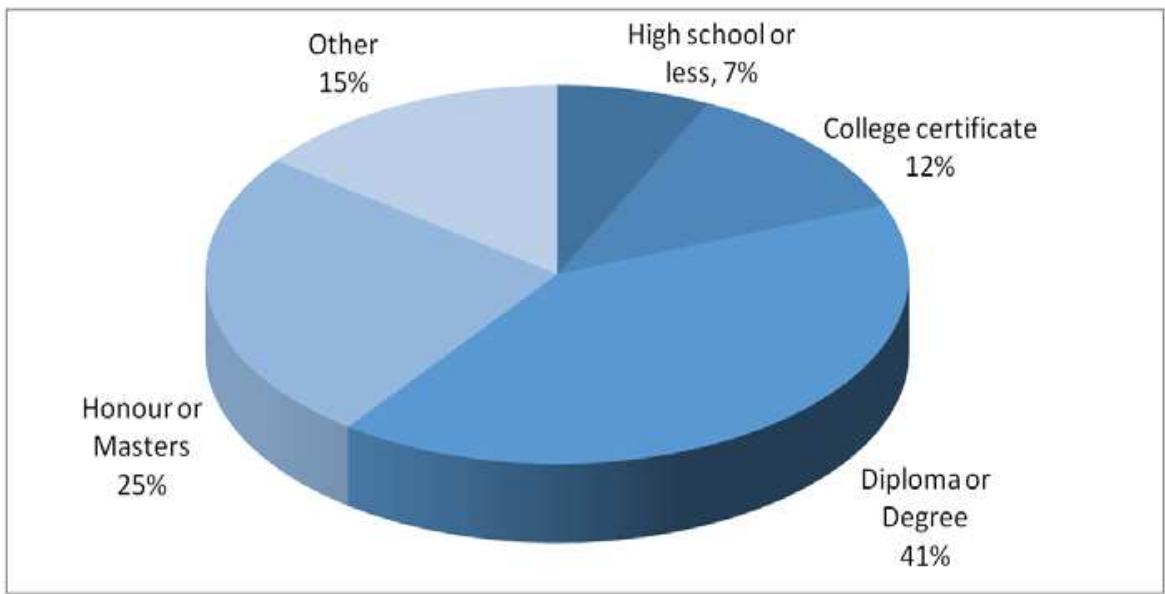

Fig. 1. Educational statuses of the respondents

3.3.4. Respondents' residence. Figure 2 provides an illustration of the population residence (location). The majority of the respondents 25.5 percent $(n=83)$ were residing in Vereeniging, followed by 24.2 percent $(n=79)$ Vanderbijlpark residents, Deneysville was represented by 16.3 percent $(n=53)$ of the respondents, 14.4 percent $(n=47)$ and 13.8 percent $(n=45)$ of the respondents represented Arconpark and Meyerton, respectively, and the small portion of the respondents 5.8 percent $(n=19)$ were from the other cities and towns within or outside of the region. This implies that Vanderbijlpark and Vereeniging is the centre of attention for online businesses with the majority of respondents.

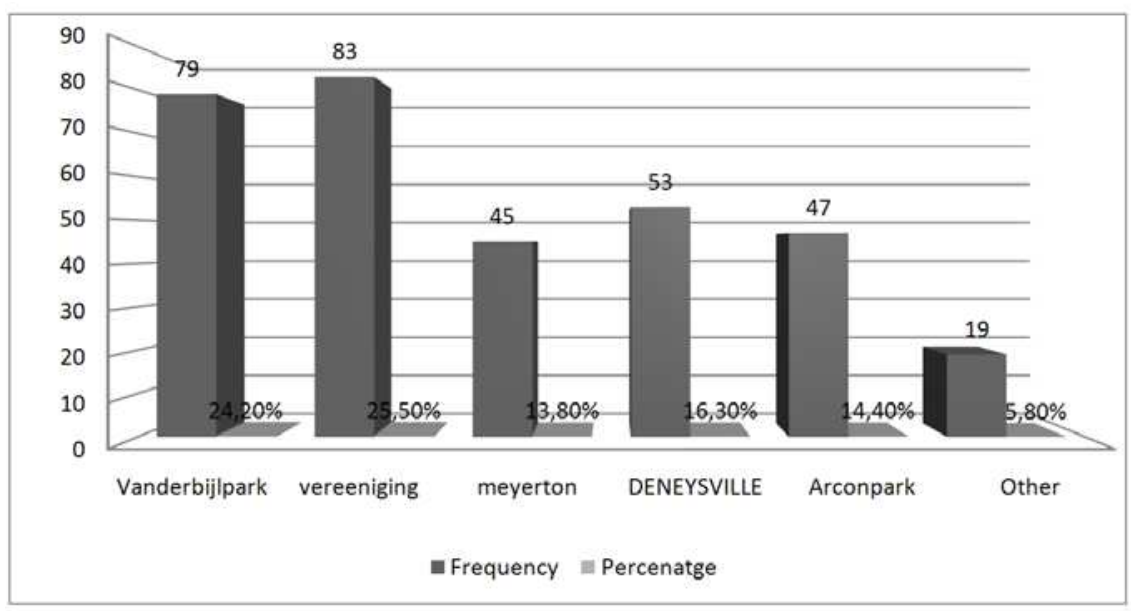

Fig. 2. Location of the respondents

3.3.5. Respondents' occupation. In terms of $(24.2 \%+37.4 \%+18.4 \%=83.6 \%)$ of the occupational level, Table 3 shows three quarters respondents were working class. This implies that 
the majority of the individuals involved in online shopping were either employed (private companies) 24.2 percent $(n=79)$, or in public companies 37.4 percent $(n=122), 18.4$ percent $(n=60)$ of the sample were professionals, $11.35(n=37)$ of the sample represented students. The remainder of the sample 8.6 percent $(n=28)$ were unemployed.

Table 3. Occupational background

\begin{tabular}{|l|c|c|}
\hline \multicolumn{1}{|c|}{ Type of work } & Frequency & Percentage \\
\hline Employee (private company) & 79 & 24.2 \\
\hline Employee (public company) & 122 & 37.4 \\
\hline Professional & 60 & 18.4 \\
\hline Unemployed & 28 & 8.6 \\
\hline Student & 37 & 11.3 \\
\hline Total & 326 & 100 \\
\hline
\end{tabular}

3.3.6. Years in online shopping and method of payment. Table 4 provides the breakdown of experience in years that the respondents had in online shopping and the terms of payment methods.

Table 4. Number of years online and the payment methods

\begin{tabular}{|l|c|c|l|c|c|}
\hline $\begin{array}{c}\text { Years shopping } \\
\text { online }\end{array}$ & Freq & $\%$ & Payment methods & Freq & $\%$ \\
\hline $\begin{array}{l}\text { Less than a } \\
\text { year }\end{array}$ & 26 & 8 & Credit card & 64 & 19.6 \\
\hline $1-3$ years & 32 & 9.8 & Debit card & 43 & 13.2 \\
\hline $4-6$ years & 97 & 29.8 & Online transfer & 102 & 31.3 \\
\hline $7-10$ years & 103 & 31.6 & Mobile phone & 63 & 19.3 \\
\hline $\begin{array}{l}10 \text { years and } \\
\text { above }\end{array}$ & 68 & 20.9 & Cash on delivery & 54 & 16.6 \\
\hline Total & 326 & 100 & Total & 326 & 100 \\
\hline
\end{tabular}

The majority of the sample 31.6 percent $(n=103)$ had been shopping online for between seven and ten years followed by 29.8 percent $(n=97)$ of the respondents with experience of four and six years, 20.9 percent $(n=68)$ represent the individuals with more than 10 years online shopping experience, individuals with between one to three years' experience were represented by $9.85(n=32)$, and the small portion of the sample 8 percent $(n=26)$ had less than a year online shopping experience. It seems that the more experience online consumers have, the more comfortable they become with online shopping transactions. This implies that online businesses are concentrated on generation- $X$ consumers with one to ten years online experience. Table 4 also reports that 31 percent $(n=102)$, which is the majority of the respondents, were using online transfer to pay for their goods or services online, 19.6 percent $(n=64)$ of the respondents used credit card for payment purposes, individuals that used mobile phones to pay for their services were represented by 19.3 percent $(n=63), 16.6$ percent $(n=54)$ and 13.2 percent $(n=$ 43) used cash on delivery and debit card, respectively. This shows that online consumers (generation-X) prefer online transfer as their source of payment when shopping or purchasing goods online.

\section{Measurement and data analysis}

4.1. Correlation analysis. In accordance with study objectives outlined in Chapter 1, it was imperative to examine the relationships between online satisfaction, loyalty and repurchase intentions. Therefore, it was necessary to employ correlations analysis among the mentioned constructs to determine the strength of the underlying relationship. The Pearson correlation coefficient (r) was used to measure the degree of linear association between the variables, as proposed by Malhotra (2010, p. 562). The composite correlation was analysed, as is reported in Table 5.

Table 5. Correlations: satisfaction, loyalty and repurchase intentions

\begin{tabular}{|l|c|c|c|c|}
\hline \multicolumn{2}{|c|}{} & Satisfaction & Loyalty & Repurchase \\
\hline \multirow{4}{*}{ Satisfaction } & Pearson correlation & 1.000 & $.791^{* *}$ & $.778^{* *}$ \\
\cline { 2 - 5 } & Sig. (2-tailed) & & .000 & .000 \\
\cline { 2 - 5 } & $\mathrm{N}$ & 326 & 326 & 326 \\
\hline \multirow{4}{*}{ Loyalty } & Pearson correlation & $.791^{* *}$ & 1.000 & $.810^{* *}$ \\
\cline { 2 - 5 } & Sig. (2-tailed) & .000 & & .000 \\
\cline { 2 - 5 } & $\mathrm{N}$ & 326 & 326 & 326 \\
\hline \multirow{3}{*}{$\begin{array}{l}\text { Repurchase } \\
\text { intention }\end{array}$} & Pearson correlation & $.778^{* *}$ & $.810^{* *}$ & 1.000 \\
\cline { 2 - 5 } & Sig. (2-tailed) & .000 & .000 & \\
\cline { 2 - 5 } & $\mathrm{N}$ & 326 & 326 & 326 \\
\hline
\end{tabular}

Notes: ** correlation is significant at the 0.01 level (2-tailed).

Table 5 shows that the relationship between satisfaction, loyalty and repurchase intentions is significantly positive. It is evident from Table 5 that the results of the Pearson correlation coefficients suggested a strong positive linear relationship between satisfaction and loyalty at $r=0.791$, $p<0.01$ level of significance, indicating that online satisfaction influences customer loyalty towards online shopping, the relationship between satisfaction and repurchase intentions is positive at $r=0.778, p<0.01$, and the table shows the positive relationship between loyalty and repurchase intentions at $r=0.810, p<0.01$.

In terms of the effect sizes, Cohen's 1988 measure of effect sizes showed a large practical significance. In assessing the size of the correlation coefficients, Cohen's d-measure of effect sizes was used to measure the significance of an effect. The size of the effect is outlined below, as conquered by Steyn (2000, p. 1):

$$
\begin{aligned}
r & =0.10 \text { (small effect); } \\
r & =0.30 \text { (medium effect); } \\
r & =0.50 \text { (large effect). }
\end{aligned}
$$

Based on the above results, it is evident that there is convergence concerning the satisfaction, loyalty and repurchase intentions in online shopping. It is 
hoped, therefore, that these findings will support and supplement the body of knowledge on the relationships among these variables. Table 6 below was used to determine the strength of the relationship between the variables, as suggested by Choudhury (2009).

Table 6. Strength of the relationships

\begin{tabular}{|l|l|}
\hline \multicolumn{1}{|c|}{ Size of $r$} & \multicolumn{1}{c|}{ Interpretation } \\
\hline$\pm(0.5$ to 1.0$)$ & Strong relationship \\
\hline$\pm(0.3$ to 0.5$)$ & Moderate relationship \\
\hline$\pm(0.1$ to 0.3$)$ & Weak relationship \\
\hline$\pm(0.0$ to 0.1$)$ & Very weak or no relationship \\
\hline
\end{tabular}

Table 6 reports that online satisfaction showed a strong relationship with loyalty $(r=0.791, p<0.01)$, satisfaction also showed a strong relationship with repurchase intentions $(r=0.778, p<0.01)$, and loyalty showed strong relationship with repurchase intentions $(r=0.810, p<0.01)$.

4.2. Regression analysis. Table 7 reports the regression analysis between online satisfaction and online customer loyalty. The predictor that was held constant was satisfaction (independent variable), and the dependent variable that was entered into the prediction model was loyalty. On the examination of the relationship between satisfaction and loyalty rating, the adjusted $R^{2}=0.624$, indicating that satisfaction explained 62.4 percent of variance on loyalty.

The beta coefficient of satisfaction $(\beta=0.791)$ suggests that there is a strong positive relationship between customer satisfaction and loyalty in online shopping. The independent variable was satisfaction, whereas the dependent variable was loyalty. Thus, satisfied customers are more likely to become loyal customers towards online shopping.

Table 7. Regression analysis: online satisfaction and online customer loyalty

\begin{tabular}{|l|l|l|l|l|}
\hline \multicolumn{1}{|c|}{ Construct } & $\mathrm{B}$ & Beta $(\beta)$ & $\mathrm{t}$ & $p$-level \\
\hline $\begin{array}{l}\text { Dependent: online customer } \\
\text { loyalty } \\
\text { Independent variable: online } \\
\text { satisfaction }\end{array}$ & 0.754 & 0.791 & 23.260 & $0.000^{*}$ \\
\hline $\mathrm{R}=0.791 \mathrm{R}^{2}=0.625 \quad$ Adjusted $\mathrm{R}^{2}=0.624 \quad \mathrm{~F}=541.015 \quad p<0.0000$ \\
\hline
\end{tabular}

Table 7 presents the regression analysis between online satisfaction and online repurchase intentions. The predictor and independent variable held constant was satisfaction, and the dependent variable was repurchase intentions. The rating (the adjusted) of the relationship between satisfaction and repurchase intentions was $R^{2}=0.604$, indicating that satisfaction explained 60.4 percent of variance on repurchase intentions.

Table 8. Regression analysis: online satisfaction and repurchase intentions

\begin{tabular}{|l|c|c|c|c|}
\hline \multicolumn{1}{|c|}{ Construct } & $B$ & Beta $(\beta)$ & $t$ & $p$-level \\
\hline $\begin{array}{l}\text { Dependent variable: repurchase intention } \\
\text { Independent variable: } \\
\text { online satisfaction }\end{array}$ & 0.741 & 0.778 & 22.297 & $0.000^{*}$ \\
\hline $\mathrm{R}=0.778 \mathrm{R}^{2}=0.605 \quad$ Adjusted $\mathrm{R}^{2}=0.604 \quad \mathrm{~F}=497.153 \mathrm{p}<0.0000$ & & \\
\hline
\end{tabular}

Table 8 presents the regression analysis between online satisfaction and online repurchase intentions. The beta coefficient of satisfaction $(\beta=0.778)$ suggests that there is a strong positive relationship between online satisfaction and online repurchase intentions. The independent variable was satisfaction, whereas the dependent variable was repurchase intentions. Thus, satisfied customers are more likely to make repeat purchases in online shopping.

Table 9. Regression analysis: online customer loyalty and repurchase intentions

\begin{tabular}{|c|c|c|c|c|}
\hline \multicolumn{1}{|c|}{ Construct } & $B$ & $\operatorname{Beta}(\beta)$ & $t$ & $p$-level \\
\hline $\begin{array}{l}\text { Dependent variable: } \\
\text { repurchase intention } \\
\text { Independent variable: } \\
\text { online customer loyalty }\end{array}$ & 0.809 & 0.810 & 24.819 & $0.000^{*}$ \\
\hline
\end{tabular}

Table 9 reports the regression analysis on the relationship between online customer loyalty and repurchase intentions. The independent variable and the predictor held constant was loyalty, and the dependent variable was online repurchase. On the examination of the relationship between these two constructs, the score (adjusted) was $\mathrm{R}^{2}=0.654$. The beta coefficient of satisfaction $(\beta=0.810)$, suggests that there is a strong positive relationship between online customer loyalty and online repurchase intentions. The dependent variable was repurchase, and the independent variable was loyalty. Therefore, the results indicate that loyal customers are more likely to make repeat purchases in an online business.

\section{Conclusion and implication}

The results of this study, although it only covered a sample from South African online shoppers, provide invaluable information to other researchers, online retailers and practitioners focusing on South African online consumers. Understanding the motivations that drive online customers to repurchase could prove worthwhile for the online businesses. The study reinforces previous areas of research, which demonstrates the value of satisfaction and loyalty in online business. It consolidates previous studies on online shopping with emphasis to the South African context and provides results of the interrelationships 
between online satisfaction, loyalty and repurchase intentions. The results indicated online satisfaction as an independent variable that prominently determines online loyalty and online repurchase intentions.

The study further extends current knowledge related to the interrelationships between online satisfaction, online loyalty and online repurchase intentions of generation- $X$ consumers. In addition, the results support the existing theoretical link of loyalty factors and repurchase intentions within the brick and mortar environment. The study shows that online customer loyalty is nearly as important as online satisfaction in influencing online repurchase intentions. This further implies that not only online satisfaction, but also online loyalty is a strong predictor of generation-X consumers' repurchase intentions through online channel. Therefore, online customer loyalty is amongst the factors affecting online customers' intentions to repurchase. In conclusion, no matter how important online customer satisfaction and loyalty are, they cannot be bought at any given price. Ultimately, the decision to devote corporate resources to such factors has to be a trade-off between the cost of achieving improvements of virtual platforms and the potential gains from doing so.

\section{Limitations}

In assessing the findings of this study, it should be noted that this study is by no means without limitations. In fact, one of its limitations was that the study was confined to only southern Gauteng online consumers. Further studies can consider the South African online shoppers as a whole. The study employed a quantitative research approach. Future research may consider both a qualitative and quantitative research design using triangulation methodology where a qualitative design could be used in generating rich ideas and explanations.

A non-probability sampling method was undertaken. Since it was difficult to locate an accurate sample frame for the study, snowball sampling was employed to generate an initial sample. Future studies could use other sampling techniques. Another limitation is the fact that the method of data collection relied on accurate introspection of each respondent. Therefore, the responses may be subject to a degree of bias. Despite these limitations, the study advances knowledge regarding online shopping satisfaction, loyalty and repurchase intention, considering that there is a noticeable absence of prior research within the South African context related to this study.

\section{References}

1. Ajzen, I. \& Fishbein, M. (1980). Understanding attitudes and predicting social behaviour. Englewood Cliffs: Prentice Hall.

2. Ajzen, I. (1991). The theory of planned behaviour, Organizational Behaviour and Human Decision Processes, 50, pp. 179-211.

3. Al-Swidi, A.K., Behjati, S. \& Shahzad, A. (2012). Antecedents of online purchasing intention among MBA students: the case of University Utara Malaysia using the partial least squares approach, International Journal of Business and Management, 7(15), pp. 35-49.

4. Awan, A.G. \& Rehman, A.U. (2014). Impact of customer satisfaction on brand loyalty-an empirical analysis of home appliances in Pakistan, British Journal of Marketing Studies, .2(8), pp. 18-32.

5. Cengiz, E. (2010). Measuring customer satisfaction: must or not, Journal of Naval Science and Engineering, 6 (2), pp. 76-88.

6. Chinomona, R., Masinge, G. \& Sandada, M. (2014). The influence of e-service quality on customer perceived value, customer satisfaction and customer loyalty in South Africa, Mediterranean Journal of Social Sciences, 5(9), pp. 331-341.

7. Donnelly, M. (2009). Building customer loyalty: a customer experience based approach in a Tourism context. Bachelor of Business Studies in Marketing. Waterford Institute of Technology.

8. Kaveh, M. (2011). Role of trust in explaining repurchase intentions, African Journal of Business Management, 6 (14), pp. 5014-5025.

9. Karami, M., Asgharizadeh, E., Khan, S.U.R., Hozhabri, A.A., Nor, K.M. \& Gashti, M.A.H. (2014). Elements affect online repurchase intentions on Malaysia's online shoppers. $8^{\text {th }}$ International Conference on e-commerce with focus on e-trust. University of Isfahan, Mashhad: Iran. 24-25 April, pp. 1-6.

10. Kim, C., Galliers, R.D., Shin, N., Ryoo, J.H. \& Kim, J. (2012). Factors influencing Internet shopping value and customer repurchase intention, Electronic Commerce Research and Applications, 11, pp. 374-387.

11. Kiyani, T.M., Niazi, M.R.U.K., Rizvi, R.Z. \& Khan, I. (2012). The relationship between brand trust, customer satisfaction and customer loyalty, Interdisciplinary Journal of Contemporary Business, 4(1), pp. 489-502.

12. Lin, C.Y., Fang, K. \& Tu, C.C. (2010). Predicting consumer repurchase intentions to shop online, Journal of Computers, 5(10), pp. 1527-1533.

13. Liu, Y.C., Chen, H.Y., Liu, C.W. \& Chan, H.Y. (2010). A model to evaluate the effectiveness of collaborative online learning teams-self-disclosure and social exchange theory perspective, International Journal of Cyber Society and Education, 3(2), pp. 117-132.

14. Luo, X. (2002). Trust production and privacy concerns on the internet: a framework based on relationship marketing and social exchange theory, Industrial Marketing Management, pp. 111-118. 
15. Morgan, R.L. (2009). Calming upset customers: Stay in control... in any situation. 4th ed. San Jose: Axzo Press.

16. Mosavi, S.A. \& Ghaedi, M. (2012). Role of perceived value in explaining trust and repurchase intention in eshopping, African Journal of Business Management, 6(14), pp. 4910-4920.

17. Myers, C.A. \& Mintu-Ndubisi, N.O., Malhotra, N.K. \& Chan, K.W. (2009). Relationship marketing, customer satisfaction and loyalty: a theoretical and empirical analysis from anAsian perspective, Journal of International Consumer Marketing, 21(1), p. 5.

18. Wimsatt, A. (2012). Exploring antecedents influencing Internet shopping satisfaction: the case of apparel industry, International Journal of Business and Social Sciences, 3(8), pp. 1-9.

19. Pérez, M., Sánchez, J.C.G., Abad, G. M., Carrillo, M. \& Fernández, R.S. (2007). Effects of service quality dimensions on behavioural purchase intentions: A study in public-sector transport, Managing Service Quality, 7, (2), pp. 134-151.

20. Pratminingsih, S.A., Lipuringtyas, C. and Rimenta, T. (2013). Factors Influencing Customer Loyalty toward Online Shopping, International Journal of Trade, Economics and Finance, 4(3), pp. 104-110.

21. Seiders, K., Voss, G.B., Grewal, D. \& Godfrey, A.L. (2005). Do satisfied customers buy more? Examining moderating influences in a retailing context, Journal of Marketing, 69 (4), pp. 26-43.

22. Shiau, W.L. \& Luo, M.M. (2012). Factors affecting online group buying intention and satisfaction: a social exchange theory perspective, Computers in Human Behaviour, 28, pp. 2431-2444.

23. Thakur, S. \& Singh, A.P. (2012). Brand image, customer satisfaction and loyalty intention: a study in the context of cosmetic product among the people of central India, International Journal of Multidisciplinary Management Studies, 2(5), pp. 37-50.

24. Tsai, H.T. \& Haung, H.C. (2007). Determinants of e-repurchase intentions: An integrative model of quadruple retention drivers, Journal of Information \& Management, 4, pp. 231-239.

25. Wen, C., Prybutok, V.R. \& Xu, C. (2011). An integrated model for customer online repurchase intention, Journal of Computer Information Systems, 18, pp. 14-23.

26. Zhang, C. \& Pan, F. (2009). The impacts of customer satisfaction on profitability. A case study of state-owned enterprises in China. Xiamen University 1(1).

27. Zhang, Y., Fang, Y., Wei, K.K., Ramsey, E., McCole, P. \& Chen, H. (2011). Repurchase intention in B2C ecommerce-a relationship quality perspective, Information Management, 48 (6), pp. 192-200. 